\title{
PENERAPAN ALGORITMA PENCARIAN KNUTH-MORRIS-PRATT (KMP) DALAM SISTEM INFORMASI PERPUSTAKAAN SMK TI PRATAMA
}

\author{
Nursobah $^{1)}$ dan Pajar Pahrudin ${ }^{2)}$ \\ ${ }^{1}$ Teknik Informatika,STMIK Widya Cipta Dharma \\ ${ }^{2}$ Sistem Informasi, STMIK Widya Cipta Dharma \\ ${ }^{1,2}$ M.Yamin No 25, Samarinda \\ E-mail : nursobah2011@gmail.com ${ }^{1)}$, pajar@wicida.ac.id ${ }^{2)}$
}

\begin{abstract}
ABSTRAK
Perpustakaan SMK TI Pratama merupakan sumber pengetahuan siswa yang dapat meningkatkan kualitas pengetahuan siswa. Sebagian besar perpustakaan sekolah swasta di samarinda masih menggunakan sistem pencarian manual untuk mencari katalog perpustakaan. Sistem yang belum terkomputerisasi tersebut menyebabkan kegiatan operasional perpustakaan berjalan lambat dan tidak efektif terutama pada penelusuran katalog perpustakaan. Maka dari itu untuk mengatasi masalah penelusuran katalog dibuat sistem penelusuran katalog perpustakaan sekolah dengan mengimplementasikan algoritma Knuth-Morris-Pratt (KMP). Algoritma Knuth- Morris-Pratt merupakan algoritma pencarian string dengan melakukan perbandingan karakter mulai dari karakter paling kanan dari string yang dicari. Sistem penelusuran katalog perpustakaan sekolah dengan mengimplementasikan algoritma Knuth-Morris-Pratt dapat mempermudah pengunjung perpustakaan sekolah untuk mengetahui jumlah dan keberadaan buku yang akan dipinjam dan mempermudah pustakawan untuk mengelola buku perpustakaan
\end{abstract}

Kata Kunci: Knuth Morris Pratt, Pencariam, Katalog Perpustakaan, SMK TI Pratama,

\section{PENDAHULUAN}

Fungsi dan wujud dari perpustakaan terus berkembang seiring dengan perkembangan peradaban manusia dari mulai zaman batu, ketika manusia menyimpan sumber pengetahuan pada lempengan batu sampai kini berada pada awal millenium ketiga yang mana sumber pengetahuan sudah banyak yang disimpan dalam bentuk digital yaitu format dari sumber pengetahuan yang dapat dimengerti oleh komputer, apalagi dengan adanya internet perpustakaan menjadi lebih fungsional. Peranan perpustakaan harus mampu menunjukkan identitasnya sebagai penyedia informasi yang representative dalam arti yang seluas-luasnya (Putera dan Ibrahim, 2018).

Artinya kehidupan dan keberadaan perpustakaan dapat menjadi rantai sejarah bagi masa lalu, akar bagi hidup dimasa sekarang ini dan pembimbing untuk melangkah kemasa depan. Adapun tujuan diselenggarakannya perpustakaan adalah untuk mendukung, memperlancar serta mempertinggi kualitas pelaksanaan program kegiatan perguruan tinggi melalui pelayanan informasi yang meliputi lima aspek yaitu pengumpulan informasi, pelestarian informasi, pengolahan informasi, pemanfaatan informasi dan penyebarluasan informasi sebagian besar perpustakaan sekolah swasta masih menggunakan sistem pencarian manual untuk mencari buku bukunya, hal ini juga terjadi di SMK TI Pratama. Sistem yang belum terkomputerisasi tersebut menyebabkan kegiatan operasional perpustakaan berjalan lambat dan tidak efektif terutama peneluran koleksi perpustakaan yang masih harus dilakukan secara manual, pengunjung harus bertanya dulu kepada admin, apakah buku yang dicari tersedia (Pratiwi et al,2018).

Sehingga diperlukan suatu sistem informasi yang dapat memecahkan permasalahan tersebut sehingga dapat mempermudah pengunjung perpustakan. Sistem penelusuran katalog perpustakaan sekolah yang akan di bangun memerlukan algoritma pencarian string yang cepat dan efektif. Implementasi algoritma Knuth-MorrisPratt (KMP) ke dalam sistem penulusuran katalog perpustakaan sekolah dapat membuat penelusuran katalog lebih cepat dan akurat sehingga pelayanan perpustakaan dapat berjalan lancar. Kelebihan dari algoritma Knuth-Morris-Pratt selain cepat juga sangat baik digunakan pada file berukuran besar karena pencarian kecocokan tidak perlu kembali ke belakang pada input teks (Sunarto,2018).

\section{RUANG LINGKUP}

Dalam penelitian ini permasalahan mencakup:

1. Bagaimana membangun sebuah sistem informasi perpustakaan yang memiliki katalog pencarian dengan cepat

2. Bagaimana mengimplementasikan algoritma KMP dalam sistem untuk mengetahui ketersediaan koleksi buku yang akan dipinjam

\section{BAHAN DAN METODE}

Penelitian tentang Algoritma pencarian telah banyak dilakukan antara lain : 
1. Penerapan algoritma $K M P$ pada posting twitter TMC polda metro jaya untuk melaporkan kondisi lalulintas dan rute jalan kota Jakarta, pada penelitian ini, algoritma Knuth-Morris-Pratt dilakukan untuk pencarian nama jalan atau lokasi beserta kondisi lalulintasnya, kemudian dilakukan visualisasi menggunakan Google Map, sehingga ketika user memilih lokasi tujuan perjalanan dari suatu tempat ke tempat lainnya di kota Jakarta maka akan ditampilkan rute jalan beserta kondisi lalulintasnya(Setiawan,2015).

2. Perbandingan algoritma Knuth-Morris-Pratt dan Turbo Boyer-Moore dalam Query MySQL, pada penelitian ini membahas perbandingan kecepatan penelusuran basis data berdasarkan query SQL. Dalam basis data dibutuhkan kecepatan yang tinggi agar proses yang menggunakan informasi tersebut dapat berjalan efektif (Siahaan,2010)

Sedangkan pada penelitian ini. algoritma yang diterapkan adalah KMP diterapkan untuk penelusuran katalog perpustakaan sekolah, dalam membuat penelusuran katalog memerlukan algoritma pencarian string yang cepat, efektif dan lebih akurat sehingga pelayanan perpustakaan dapat berjalan dengan lancar.

\subsection{Knuth-Morris-Pratt}

Algoritma Knuth-Morris-Pratt adalah salah satu algoritma pencarian string, dikembangkan secara terpisah oleh Donald E. Knuth pada tahun 1967 dan James H. Morris bersama Vaughan R. Pratt pada tahun 1966, namun keduanya mempublikasikannya secara bersamaan pada tahun 1977 (Manikandan dan Ramyachitra,2018).

Jika kita melihat algoritma KMP lebih mendalam, kita mengetahui bahwa dengan mengingat beberapa perbandingan yang dilakukan sebelumnya kita dapat meningkatkan besar pergeseran yang dilakukan. Hal ini akan menghemat perbandingan, yang selanjutnya akan meningkatkan kecepatan pencarian.

Perhitungan penggeseran pada algoritma ini adalah sebagai berikut, bila terjadi ketidakcocokkan pada saat pattern sejajar dengan teks[i..i+n-1], dapat menganggap ketidakcocokan pertama terjadi di antara teks $[i+j]$ dan pattern $[j]$, dengan $0<j<n$. Berarti, teks $[i . . i+j-$ $1]=$ pattern $[0 . . j-1]$ dan $a=t e k s[i+j]$ tidak sama dengan $b=$ pattern $[j]$. Ketika kita menggeser, sangat beralasan bila ada sebuah awalan $v$ dari pattern akan sama dengan sebagian akhiran $u$ dari sebagian teks. Sehingga kita bisa menggeser pattern agar awalan $v$ tersebut sejajar dengan akhiran dari $u$.

Dengan kata lain, pencocokkan string akan berjalan secara efisien bila kita mempunyai tabel yang menentukan berapa panjang kita seharusnya menggeser seandainya terdeteksi ketidakcocokkan di karakter ke- $j$ dari pattern. Tabel itu harus memuat next $[j]$ yang merupakan posisi karakter pattern $[j]$ setelah digeser, sehingga kita bisa menggeser pattern sebesar $j$-next $[j]$ relatif terhadap teks. (Sunarto,2018;Jimale et al,2018).
Secara sistematis, langkah-langkah yang dilakukan algoritma Knuth-Morris-Pratt pada saat mencocokkan string:

1. Algoritma Knuth-Morris-Pratt mulai mencocokkan pattern pada awal teks.

2. Dari kiri ke kanan, algoritma ini akan mencocokkan karakter per karakter pattern dengan karakter di teks yang bersesuaian, sampai salah satu kondisi berikut dipenuhi:

1) Karakter dipattern dan di teks yang dibandingkan tidak cocok (mismatch).

2) Semua karakter di pattern cocok. Kemudian algoritma akan memberitahukan penemuan di posisi ini.

3. Algoritma kemudian menggeser pattern berdasarkan tabel next, lalu mengulangi langkah 2 sampai pattern berada di ujung teks.

\subsection{Metode Air Terjun}

Model air terjun (waterfall) adalah model satu arah yang dimulai dari tahap persiapan sampai perawatan, dan model inilah yang dipakai oleh penulis dalam menganalisa sistem yang akan dikerjakan

1. Analisis data sistem ini bertujuan untuk memberikan gambaran tentang sistem yang diusulkan, menganalisa teknologi yang dibutuhkan

2. Desain sistem ini bertujuan untuk memberikan gambaran umum tentang sistem yang diusulkan. Desain yang digunakan adalah Diagram Alir (Flowchart)

3. Coding \&Testing yaitu dalam hal ini difokuskan pada pembuatan program dan penggunaannya. Pada tahap ini bertujuan untuk meletakkan algoritma KMP yang di buat agar siap untuk dioperasikan atau dijalankan.

4. Penerapan / pengujian program, Metode pengujian ini menggunakan metode pengujian white- box. Pengujian ini digunakan untuk untuk memastikan bahwa semua statemen pada program telah dieksekusi paling tidak satu kali selama pengujian dan bahwa semua kondisi logis telah diuji

5. Pemeliharaan Perangkat lunak yang sudah disampaikan kepada pelanggan pasti akan mengalami perubahan. Perubahan tersebut bisa karena mengalami kesalahan karena perangkat lunak harus menyesuaikan dengan lingkungan (periperal atau sistem operasi baru) baru, atau karena pelanggan membutuhkan perkembangan fungsional.

Setiap tahapan dilakukan secara berurutan mulai dari langkah pertama sampai langkah terakhir, setiap langkah yang telah selesai dikerjakan harus dilakukan pengkajian ulang, tertera dalam gambar 1 berikut : 


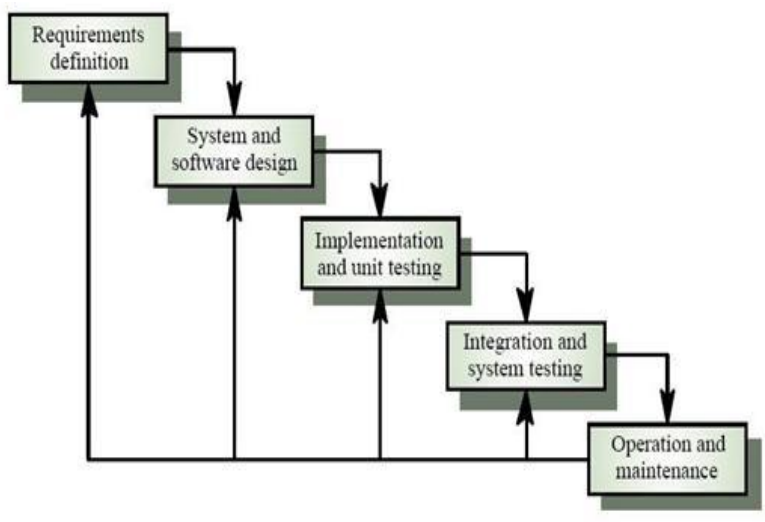

Gambar 1. Gambaran Sistem

\section{PEMBAHASAN}

Berikut disajikan hasil analisis dan implementasi dari penerapan algoritma pada sistem yang dibangun

\subsection{Analisa Implementasi algoritma Knuth Morris Pratt dalam sistem pencarian buku}

Secara sistematis, langkah-langkah yang dilakukan algoritma Knuth Morris Pratt pada saat mencocokkan string yaitu (Ramadhani, 2017):

1. Masukkan Query kata yang akan dicari. Dengan permisalan $\mathrm{P}=$ Pattern atau pola susunan kata yang dijadikan sebagai contoh atau pola teks yang akan dicari $\mathrm{T}=$ Teks atau judul dokumen.

2. Algoritma Knuth Morris Pratt mulai mencocokkan pattern atau pola susunan kata yang dijadikan sebagai contoh pada awal teks.

3. Dari kiri ke kanan, algoritma ini akan mencocokkan karakter per karakter patternatau pola susunan kata yang dijadikan sebagai contoh dengan karakter di teks yang bersesuaian, sampai salah satu kondisi berikutdipenuhi yaitu :

1) Karakter di patternatau pola susunan kata yang dijadikan sebagai contoh dan di teks yang dibandingkan tidak cocok (mismatch).

2) Semua karakter di patternatau pola susunan kata yang dijadikan sebagai contoh cocok. Kemudian algoritma akan memberitahukan penemuan di posisi ini.

4. Algoritma kemudian menggeser patternatau pola susunan kata yang dijadikan sebagai contoh berdasarkan tabel next, lalu mengulangi langkah no. 2 sampai patternatau pola susunan kata yang dijadikan sebagai contoh berada di ujung teks.

Perhitungan manual pada algoritma Knuth-Morris-Pratt digunakan untuk membuat gambaran kasar dari cara kerja algoritma tersebut. Data pada perhitungan manual ini diambil dari salah satu data nyata yang ada pada database terlihat pada tabel 1 sampai 7 .

String : risalah

Pattern: salah
Tabel 1. Pattern tidak cocok dengan string

\begin{tabular}{|l|l|l|l|l|l|l|l|}
\hline String & $\mathrm{R}$ & $\mathrm{i}$ & $\mathrm{s}$ & $\mathrm{a}$ & $\mathrm{l}$ & $\mathrm{a}$ & $\mathrm{h}$ \\
\hline Pattern & $\mathrm{S}$ & $\mathrm{a}$ & $\mathrm{l}$ & $\mathrm{a}$ & $\mathrm{h}$ & & \\
\hline
\end{tabular}

LangkahI :Pattern tidak cocok dengan string. Maka pattern akan bergeser satu posisi ke kanan.

Tabel 2. Pattern tidak cocok dengan string kembali

\begin{tabular}{|l|l|l|l|l|l|l|l|}
\hline String & $\mathrm{R}$ & $\mathrm{i}$ & $\mathrm{s}$ & $\mathrm{a}$ & $\mathrm{l}$ & $\mathrm{a}$ & $\mathrm{h}$ \\
\hline Pattern & & $\mathrm{S}$ & $\mathrm{A}$ & $\mathrm{l}$ & $\mathrm{a}$ & $\mathrm{h}$ & \\
\hline
\end{tabular}

LangkahII: Pattern tidak cocok dengan string. Maka pattern akan bergeser satu posisi ke kanan.

Tabel 3. Pencocokan pattern dengan string kembali

\begin{tabular}{|l|l|l|l|l|l|l|l|}
\hline String & $\mathrm{R}$ & $\mathrm{i}$ & $\mathrm{S}$ & $\mathrm{a}$ & $\mathrm{l}$ & $\mathrm{a}$ & $\mathrm{h}$ \\
\hline Pattern & & & $\mathrm{S}$ & $\mathrm{a}$ & $\mathrm{l}$ & $\mathrm{a}$ & $\mathrm{h}$ \\
\hline
\end{tabular}

LangkahIII: Pattern cocok dengan string. Karena ada keocokan, maka algoritma Knuth Morris Pratt akan menyimpan informasi ini, dan pattern tidak akan melakukan pergeseran dan melanjutkan pencocokan pattern dengan string.

Tabel 4. Pattern cocok dengan string

\begin{tabular}{|l|l|l|l|l|l|l|l|}
\hline String & $\mathrm{R}$ & $\mathrm{i}$ & $\mathrm{s}$ & $\mathrm{a}$ & $\mathrm{l}$ & $\mathrm{a}$ & $\mathrm{h}$ \\
\hline Pattern & & & $\mathrm{S}$ & $\mathrm{a}$ & $\mathrm{l}$ & $\mathrm{a}$ & $\mathrm{h}$ \\
\hline
\end{tabular}

LangkahIV : Pattern cocok dengan string. Karena ada keocokan, maka algoritma Knuth Morris Pratt akan menyimpan informasi ini, dan pattern tidak akan melakukan pergeseran dan melanjutkan pencocokan pattern dengan string.

Tabel 5. Pattern cocok dengan string kembali

\begin{tabular}{|l|l|l|l|l|l|l|l|}
\hline String & $\mathrm{R}$ & $\mathrm{i}$ & $\mathrm{s}$ & $\mathrm{a}$ & $\mathrm{l}$ & $\mathrm{a}$ & $\mathrm{h}$ \\
\hline Pattern & & & $\mathrm{S}$ & $\mathrm{a}$ & $\mathrm{l}$ & $\mathrm{a}$ & $\mathrm{h}$ \\
\hline
\end{tabular}

LangkahV : Pattern cocok dengan string. Karena ada keocokan, maka algoritma Knuth Morris Pratt akan menyimpan informasi ini, dan pattern tidak akan melakukan pergeseran dan melanjutkan pencocokan pattern dengan string.

Tabel 6. Pattern cocok dengan string indeks ke-6

\begin{tabular}{|l|l|l|l|l|l|l|l|}
\hline String & $\mathrm{R}$ & $\mathrm{i}$ & $\mathrm{s}$ & $\mathrm{a}$ & $\mathrm{l}$ & $\mathrm{a}$ & $\mathrm{h}$ \\
\hline Pattern & & & $\mathrm{S}$ & $\mathrm{a}$ & $\mathrm{l}$ & $\mathrm{a}$ & $\mathrm{h}$ \\
\hline
\end{tabular}

LangkahVI : Pattern cocok dengan string. Karena ada keocokan, maka algoritma Knuth Morris Pratt akan menyimpan informasi ini, dan pattern tidak akan melakukan pergeseran dan melanjutkan pencocokan pattern dengan string. 
Tabel 7. Pattern cocok dengan string indeks ke-7

\begin{tabular}{|l|l|l|l|l|l|l|l|}
\hline String & $\mathrm{R}$ & $\mathrm{i}$ & $\mathrm{s}$ & $\mathrm{a}$ & $\mathrm{l}$ & $\mathrm{a}$ & $\mathrm{h}$ \\
\hline Pattern & & & $\mathrm{S}$ & $\mathrm{a}$ & $\mathrm{l}$ & $\mathrm{a}$ & $\mathrm{h}$ \\
\hline
\end{tabular}

LangkahVII : Pattern cocok dengan string. Karena ada keocokan, maka algoritma Knuth Morris Pratt akan menyimpan informasi ini, dan pattern tidak akan melakukan pergeseran dan melanjutkan pencocokan pattern dengan string. Namun karena jumlah pattern hanya 6 huruf, maka pencarian akan dihentikan dan diperoleh hasil bahwa pattern $\mathrm{P}$ terdapat kecocokan dengan string S sebesar 100 persen.

\subsection{Tampilan Antarmuka Pencarian Dalam Sistem}

Berikut ini merupakan tampilan dari form pencarian buku, pada form user menginputkan buku akan menampilkan data alternatif dari database yang sudah diinputkan.

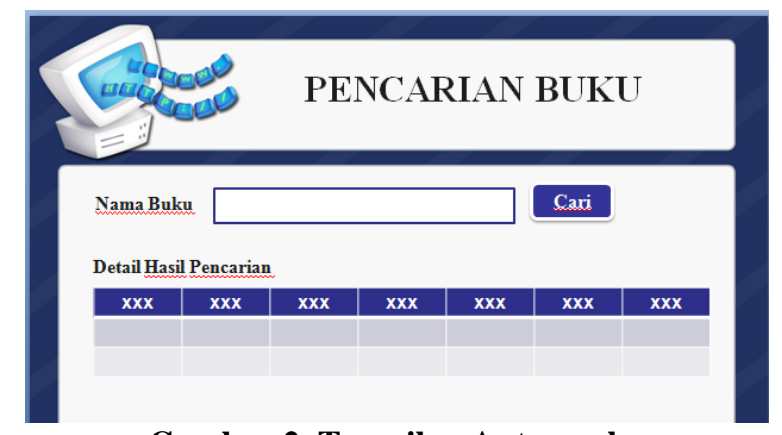

Gambar 2. Tampilan Antarmuka

\section{KESIMPULAN}

Kesimpulan yang diperoleh dari penelitian adalah dengan mengimplementasikan Algoritma Knuth-MorrisPratt dapat membantu meringankan kerja petugas atau admin dalam memberi laporan jumlah buku yang tersedia diperpustakaan, dan juga dalam melayani pengunjung yang ingin mengetahui koleksi buku diperpustakaan SMK TI Pratama.

\section{SARAN}

Untuk perkembangan dapat menambahkan aplikasi simpan pinjam buku dan pengembalian buku. Dan Algoritma Knuth Morris Pratt dapat digantikan dengan algoritma pencarian string yang lain seperti algoritma Boyer Moore.

\section{DAFTAR PUSTAKA}

Jimale, A. O., Zainon, W. M. N. W., \& Abdullahi, L. F. 2018. Spell Checker for Somali Language Using Knuth-Morris-Pratt String Matching Algorithm. In
International Conference of Reliable Information and Communication Technology (pp. 249-256). Springer, Cham

Manikandan, P., \& Ramyachitra, D. 2018. PATSIM: Prediction and analysis of protein sequences using hybrid Knuth-Morris Pratt (KMP) and Boyer-Moore (BM) algorithm. Gene, 657, 5059.

Pratiwi, D., Hartini, S., \& Marlina, S. 2018. Rancang Bangun Sistem Informasi Perpustakaan Pada Sekolah SMK Yadika 13 Tambun Utara Berbasis WEB. Paradigma-Jurnal Komputer dan Informatika, 20(1), 53-58.

Putera, A. R., \& Ibrahim, M. 2018. Rancang Bangun Sistem Informasi Peminjaman dan Pengembalian Buku Perpustakaan SMP Negeri 1 Madiun. Doubleclick: Journal of Computer and Information Technology, 1(2), 57-61.

Ramadhani, d. 2017. Perancangan aplikasi pencarian buku pada perpustakaan islamic international school darul ilmi murni dengan algoritma knuth morris pratt. Pelita informatika: informasi dan informatika, 16(1).

Setiawan, Rudi. 2015. Penerapan Algoritma KMP Pada Posting Twitter TMC Polda Metro Jaya Untuk Melaporkan Kondisi Lalulintas Dan Rute Jalan Kota Jakarta. Jurnal Informatika Vol 9. Jakarta.Hal 10-16 http://journal.uad.ac.id

Siahaan, Margaretha. 2010. Perbandingan Algoritma Knuth-Morris-Pratt fan Turbo Boyer- Moore Dalam Query MySQL. Makalah IF3051 Strategi Algoritma. Bandung. Hal 1-5 http://informatika.stei.itb.ac.id

Sunarto, Y. K. 2018. Studi Perbandingan Algoritma Naive Method, Knuth-Morris-Pratt dan BoyerMoore-Hoorspool pada Multi Record Database (Doctoral dissertation, Program Studi Teknik Informatika FTI-UKSW).

\section{UCAPAN TERIMA KASIH}

Dengan segala kerendahan hati, penulis ingin mengucapkan terima kasih kepada

Allah SWT atas rahmat dan karunia-Nya

Direktorat Riset dan Pengabdian Masyarakat, Direktorat Jenderal Penguatan Riset dan Pengembangan

Kementerian Riset, Teknologi, dan Pendidikan Tinggi sesuai dengan Kontrak Penelitian Tahun Anggaran 2019

Dan kepada teman-teman yang telah banyak membantu dan memberikan motivasinya 